\title{
РОЗВИТОК НАРОДНОЇ ШКОЛИ В УКРАЇНІ (ДРУГА ПОЛОВИНА ХІХ - ПОЧАТОК ХХ СТОЛІТТЯ)
}

\begin{abstract}
Ємельова А. П. Розвиток народної школи в Украйні (друга половина XIX - початок ХХ століття).

У статті розглянуто розвиток народної школи в Україні у другій половині ХІХ - на початку ХХ століття. Подано загальну характеристику народних икіл, підпорядкованих різним міністерствам та відомствам, які були основними початковими навчальними закладами для народу.

Ключові слова: народна школа, народне училище, початкове училище, земська, міністерська, міська, иерковнопарафіяльна школа та школа грамоти.

Емелева А. П. Развитие народной школьв в Украине (вторая половина ХІХ-начало ХХ века)

В статье рассматривается развитие народной школь на Украине в конце XIX-в начале ХХ века. Характеризуются народные школь различного ведомственного подчинения, которые были основными начальными учебныли заведениями для народа.
\end{abstract}

Ключевые слова: народная школа, народное училище, начальное училище, земская, министерская, городская, церковно-приходская школа и школа грамотности.

Emeleva A. The devepment of public school in the Ukraine (second half of the xix th-beginning of the $x x$ th century).

In the article the processes of the development of primary school in the Ukraine (second half of the XIX th - beginning of the XX th century) are under the author's consideration. The general characteristic of public schools is given, the role of the state, church, zemstvo and community in spreading literacy in the Ukraine is described.

Key words: public schools, zemstvo's schools, ministerial schools, church-parish schools, city schools, elementary schools, schools of literacy.

Демократичні процеси, що відбуваються в сучасному українському суспільстві (демократизація, реформування освіти, досягнення науки), грунтуються на національних та історичних надбаннях українського народу. Дослідження й аналіз наукових праць науковців і педагогів-практиків дореволюційного періоду засвідчують, що однією 3 основних освітянських проблем був розвиток народної школи.

Історію становлення і розвитку народної освіти України другої половини XIX - початку XX століття відображено в дослідженнях О. Білецького, I. Зайченка, О. Сухомлинської та інших. Водночас потребує уточнення питання розвитку народної школи зазначеного періоду.

Meта статmi - висвітлити етапи розвитку народного шкільництва й подати загальну характеристику типів народних шкіл.

Період другої половини XIX - початку XX ст. характеризувався подальшою колонізацією українських земель, що входили до Російської імперії. Після скасування кріпосного права (1861р.) на Україні розпочався інтенсивний процес розвитку початкової освіти.

Перетворення суспільних відносин (скасування кріпосного права) потребувало здійснення суспільно-політичних змін, особливо в галузі 
місцевого самоврядування, судової системи, освіти та фінансів. Відтак реформи 60-70 рр. знайшли своє відображення у розвитку шкільної освіти.

14 липня 1864 р. прийнято «Положення про початкові народні училища», згідно з яким початкові школи оголошувалися відкритими для всіх соціальних верств населення. У цих школах передбачалося «утвердження поміж народу релігійних i моральних понять i поширення початкових корисних знань».

Дослідник народної освіти О. Білецький зазначає, що «Положення» затвердило однокласні і двокласні початкові училища як навчальні заклади для найбіднішого населення, тобто для широких народних мас, тому поняття «народна освіта»і початкова «освіта» пореформеного періоду стали тотожними [1].

Для позначення початкової ланки в системі освіти науковці вживають, як правило, поняття «початкова школа», «народна школа», «початкове народне училище», «народне училище» [5, с.35].

Український педагогічний словник подає поняття «народна школа» («народне училище») та «початкове училище» як синонімічні та витлумачує їх як «загальноосвітні навчальні заклади початкового навчання, єдино доступні в Російській імперії для дітей всього населення» [3, с. 227].

До початкових шкіл входили школи всіх відомств, міські та сільські, а також навчальні заклади, які утримувалися за рахунок скарбниці, громадських і приватних осіб.

«Положення» 14 липня 1864 р. розповсюджувалося на міські парафіяльні i сільські початкові училища, залишивши за ними навчальний курс, затверджений статутом 1828 р., а саме: Закон Божий (молитви, короткий катехізис та свята історія); читання по книгам громадського та церковного видавництва; письмо; перші чотири дії арифметики та церковний спів. Окрім того, згідно зі статутом 1828 року, до нижчих училищ входили також трикласні повітові училища, які оминуло «Положення» 1864 р. Тому керівництво навчальних округів клопотало перед міністерством народної освіти про реорганізацію повітових училищ. Складений міністерством проект «Положення про міські училища та учительські інститути» було затверджено 31 травня 1872 р. Згідно з «Положенням» повітові училища реорганізовано в дво-, три- та чотирикласні міські початкові училища [2, с. 321-323]. Однак процес реорганізації повітових училищ не був завершений. У 1894 р. залишалось 147 повітових училищ, в яких навчалося близько 12 тис. учнів [4, с. 321].

У міських училищах викладалися закон Божий, читання та письмо; російська мова та церковно-слов'янське читання, з перекладом на російську мову; арифметика, 3 додатками 3 практичного рахівництва; практична геометрія; географія та історія вітчизни, 3 необхідними відомостями із загальної історії та географії; відомості із природознавчої історії та фізики; креслення та малювання; співи й гімнастика [2, с. 323]. 
Окрім зазначених предметів учні в міських училищах за бажанням батьків та додаткову плату могли вивчати у позакласний час найпростіші ремесла: палітурне, токарне та інші для розвитку технічних здібностей.

Міські училища посідали чільне місце в розвитку системи народної освіти. На відміну від повітових училищ, які навчали дітей заможних купців, ремісників та інших станів городян, міське училище давало змогу отримати початкову освіту широким колам міського населення.

Підпадаючи під безпосередній контроль Міністерства народної освіти, міські школи водночас підпорядковувалися і повітовим земствам. Повітові земства зобов'язувалися фінансувати ці заклади та забезпечувати організацію навчання. У 1912 р. міські училища реорганізовано у вищі навчальні школи 3 чотирирічним терміном навчання (після початкової школи).

25 травня 1874 р. прийнято нове «Положення про початкові народні училища», головне завдання якого полягало в «охороні справи народної освіти від сторонніх пагубних впливів, підтримці і зміцненні цього у дусі релігії». Це завдання покладалося на спільні зусилля Міністерства народної освіти, духовенства і дворянства. Згідно з Положенням початкові народні школи засновувалися земством, міськими та сільськими громадами та приватними особами $з$ попереднього дозволу інспектора народних училищ та за згодою голови початкової шкільної ради.

До училищ приймалися діти всіх станів, плата за навчання встановлювалася відомством чи приватними особами, на кошти яких утримувалися училища. Початкові народні училища перебували під наглядом училищної ради, хоча за релігійним вихованням мав стежити парафіяльний священик.

До початкових училищ у Російській імперії, а отже й в Україні, належали школи Міністерства народної освіти (міністерські), церковнопарафіяльні школи, які функціонували паралельно зі школами грамоти. Широкого розповсюдження отримали земські народні школи, що в основному концентрувалися в сільській місцевості. Крім того, функціонували міські школи, відомчі (наприклад, школи залізничних доріг тощо), приватні школи та пансіони. Слід зазначити, що особливістю деяких губерній, зокрема Катеринославської, була наявність шкіл національних меншин: єврейських, німецьких, болгарських та ін.

Земські школи відкривалися й утримувалися земствами у сільській місцевості після земської реформи 1864 р. Передовсім земці піклувалися про матеріальну забезпеченість шкіл. Кращі представники училищних рад від земств дбали про будівництво шкільних приміщень, про забезпечення учнів шкіл підручниками, посібниками, письмовим приладдям. Задля трудової підготовки учнів, запроваджували у школах уроки ручної праці, створювали шкільні майстерні, пришкільні земельні ділянки і сади.

Земські школи були у другій половині XIX століття новим типом народної школи, в якій доцільно поєдналися суспільні інтереси та народні традиції, прагнення до виховання моральних якостей та фізичного розвитку 
особистості, любові до праці як загальнолюдської потреби та орієнтації на особисте селянське господарство.

Підвищення інтересу народу до освіти і значні матеріальні вкладення земств та сільських общин у шкільне будівництво забезпечили швидке зростання і розвиток земської школи. Налякане розмахом громадськості i народної ініціативи, уряд створює зразкові однокласні та двокласні «міністерські» школи, що діяли за Положенням 1869 р. «Про заснування міністерських одно- та двокласних училищ». Міністерство народної освіти відкривали школи саме тому вони називалися міністерськими. Для відкриття таких шкіл необхідним було зобов'язання сільського сходу у виділенні безкоштовного земельного наділу і взяття витрат на утримання. Навчання в міністерських школах, як правило, було роздільним. Спільне навчання допускалося лише в тому випадку, коли хлопці були не старші 14 років, а дівчата - 12 і сиділи на різних лавах. Курс навчання в однокласному міністерському училищі тривав три роки. Викладались закон Божий, російська мова з чистописанням, арифметика, церковний спів.

Уряд царської Росії велику увагу приділяв релігійному навчанню та вихованню, відтак при церковних парафіях створювалися початкові школи, які повністю підпорядковувалися Святішому Синоду. Для завідування церковнопарафіяльними школами створені єпархіальні училищні ради, склад яких добирався єпархіальними архієреями.

В однокласних церковнопарафіяльних школах викладали Закон Божий (вивчення молитов, священна історія і пояснення богослужіння, короткий катехізис), церковний спів, читання церковного i громадського друку, письмо, початкові арифметичні відомості. У двокласних школах вказані предмети доповнювалися російською мовою та церковною історією. Крім обов'язкових предметів у деяких церковнопарафіяльних школах викладали ручну працю та рукоділля.

Статус шкіл грамоти визначався нижчим за статус церковнопарафіяльної. Школи поділялися на однокласні з дворічним курсом і двокласні з чотирирічним курсом навчання, де грамоти навчали дітей письму, читанню, арифметиці, закону Божому, церковному співу тощо. Досить часто вибір предметів, які вивчалися в навчальних закладах такого типу, визначався й можливістю громади оплачувати роботу вчителя. За наявності вільних коштів на рахунку общини, iї члени рішенням загального сходу села могли найняти для своїх дітей спеціалістів і $з$ інших предметів, а саме: учителя гімнастики, рукоділля, ремесла тощо.

У середині 1890-х років, відповідно до загальної кількості народних шкіл, церковні училища складали 23\% і школи грамоти 35 \%, перемістивши земські школи на друге місце (36 \%), які все ж випереджали церковну школу за кількістю учнів. Загалом, кількість церковних шкіл на початку XX ст. становила близько 46,5 \% усіх початкових шкіл [3, с. 248].

Після приєднання жителів німецьких колоній до сільського населення перетворення колоністів в «поселян-власників» усі колоністські школи були 
приєднані до складу церковнопарафіяльних й почали називатися у звітах «народними училищами в колишніх німецьких колоніях».

Основними типами єврейських шкіл були талмуд-тори (релігійні єврейські училища для сиріт і бідняків) та хедери (єврейська початкова школа для хлопчиків). Талмуд-тори функціонували за рахунок єврейських громад та на добровільні пожертви. Деякі представники єврейського населення навчалися в приватних школах, де загальним предметам відводилося більше часу, ніж єврейським. Окрім єврейських предметів (алфавіт, молитви, біблейська історія і основи іудаїзму) викладалася російська мова, арифметика, історія географії, природознавство, гімнастика та ручна праця.

Наприкінці XIX ст. в українських губерніях діяло 16798 початкових шкіл, які перебували у підпорядкуванні різних відомств.

Слід зазначити, що початкові школи тривалий час не мали державних навчальних програм i лише у 1897 р. Міністерством народної освіти публікуються «Приблизні навчальні програми» для початкових шкіл.

В однокласних початкових школах учні вивчали закон Божий, церковнослов'янську грамоту, російську мову (граматика, письмо, читання), арифметику, співи. Під час вивчення російської мови мало місце пояснювальне читання, де учні одержували елементарні відомості з історії, географії та природознавства. Дещо вищого рівня знань учні набували у двокласних училищах 3 п'ятирічним терміном навчання, що відкривалися у великих селах та на залізничних станціях. Перші три роки навчання складали перший клас та відповідали початковому (однокласному) училищу; четвертий та п’ятий рік навчання були другим класом. У цьому класі викладались закон Божий, російська мова з елементарними відомостями по російській літературі, математика (арифметика та геометрія), історія, географія, природознавство, елементарні відомості 3 фізики, малювання та креслення та деякі необов'язкові предмети (ручна праця, рукоділля, гімнастика тощо).

Революційні події 1905 р. в Росії висунули вимоги реформування школи і системи освіти. Царськими указами цього періоду разом 3 проголошенням свободи зборів друку, слова, спілок з'явилася реальна можливість відродження національного шкільництва.

Уведення закону про загальну освіту у 1908 р. сприяло зростанню кількості народних училищ, які перебували в підпорядкуванні різних міністерств і відомств, громадських організацій та приватних осіб. Відтак кількість початкових шкіл в Україні зросла приблизно з 17 тис. у 1897 р. до 19 тис. у 1914-1915 pp.

Отже, на початку XX століття в Україні сформувалася певна система національного шкільництва, до якої входили початкові школи Міністерства народної освіти (міністерські народні училища, міські училища (за «Положенням» 1872 р.), органів місцевого самоврядування (земські школи), приватних осіб, Святого Синоду (церковнопарафіяльні школи, школи грамоти, та монастирські школи). 


\section{Література}

1. Білецький О. П. Розвиток народної освіти у Катеринославській губернії (друга половина XIX - початок XX ст.) : автореф. дис. на здобуття наук. ступеня канд. пед. наук : спец. 13.00.01 «Історія педагогіки» / О. П. Білецький. - Луганськ, 2009. - 20 с.

2.Вессель Н. Руководство к преподаванию общеобразовательных предметов. Т 1. Общая часть. - Первый отдел. Исторический очерк общеобразовательных училищ и психологические основания общего образования - СПб : Типография В. С. Балашева, 1873. - XX, $598 \mathrm{c}$.

3.Гончаренко С. Український педагогічний словник / С. Гончаренко - К. : Либідь, 1997. $-376 \mathrm{c}$.

4.Зайченко I. В. Історія педагогіки. У двох книгах. Книга II. Школа, освіта i педагогічна думка в Україні. Навчальний посібник для студентів вищих навчальних закладів. - К. : Видавничий дім “Слово”, 2010 - 1032 с.

5.Нариси 3 історії українського шкільництва, 1905-1933 : [навч. посібник] / О. В. Сухомлинська та ін., за ред. О. В. Сухомлинської. - К. : Заповіт, 1996. - 304 с.

Стаття надійшла до редакції 28.05.2012 р.

УДК 379.89 .045

О. О. Гаврилюк, кандидат пед.наук, доцент,

В. В. Іванова, кандидат пед.наук, дочент, Криворізький педагогічний інститут ДВНЗ «Криворізький національний університет»

\section{ОСОБЛИВОСТІ КОМПЕТЕНТНІСНОГО ПІДХОДУ В ОРГАНІЗАЦЇ̈ САМОСТІЙНОЇ НАВЧАЛЬНОЇ ДІЯЛЬНОСТІ СТУ ДЕНТІВ 3 IHOЗЕМНОÏ МОВИ}

Гаврилюк О. О., Іванова В.В. Особливості компетентнісного підходу в організації самостійної навчальної діяльності студентів з іноземної мови.

У статті висвітлено зміст та значення компетентнісного підходу щзодо організації самостійної навчальної діяльності студентів вищих педагогічних навчальних закладів. Розкрито поняття «ключова компетентність» та проаналізовано основні компоненти самостійної навчальної діяльності студентів.

Ключові слова: компетентнісний підхід, ключова компетентність, самостійна навчальна діяльність.

Гаврилюк О. А., Иванова В. В. Особенности компетентносного подхода в организации самостоятельной учебной деятельности студентов по иностранному языку.

В статье освещены содержание и значение компетентносного подхода при организации самостоятельной учебной работы студентов высших педагогических учебных заведений. Раскрыто понятие «ключевая компетентность», a также анализируются основные компоненты самостоятельной учебной деятельности студентов.

Ключевые слова: компетентносный подход, ключевая компетентность, самостоятельная учебная деятельность.

Gavrilyuk O., Ivanova V. Features kompetentnosnogo approach to the organization of independent learning activities of students in a foreign language.

The article deals with the content and meaning of competence approach concerning the organization of the students' independent educational activities at higher pedagogical institutions. The notion "key competence" is illuminated and the main components of the students' independent educational activities are analysed.

Key words: competence approach, key competence, independent educational activities. 